\title{
Assessment of industrial wastes in mortar layers deposited on stainless steel sheets of sinks
}

\section{(Avaliação de resíduos industriais em camadas de argamassas depositadas sobre chapas de aço inoxidável de pias)}

\author{
E. Gemelli, S. Lourenci, M. V. Folgueras, N. H. Almeida Camargo \\ Department of Mechanical Engineering, Center of Technological Sciences \\ UDESC - Santa Catarina State University \\ PO Box 631, Joinville, SC, Brazil 89223-100
}

\begin{abstract}
This work deals with the properties of alternative mortars destined to strengthen metal sheets of sinks. The performance of these mortars was compared to that of a basic mortar made of cement, sand, and water, named standard mortar (SM). One of these mortars, named alternative mortar 2 (AM2), and composed of cement, textile residue, polyurethane, polypropylene fibers and water, was developed recently to replace the current one, named alternative mortar 1 (AM1), composed of cement, sand, polystyrene, polypropylene fibers and water. These mortars were manufactured and aged in a room in atmospheric environment for 7, 14, 28, 60 and 90 days, either with or without initial drying in a furnace. After cure of 90 days the flexion strength stress of the SM, AM1 and AM2 mortars was 5.21, 3.84, and 1.42 MPa, respectively. The SM and AM1 mortars were constituted of C-S-H phases, $\mathrm{Ca}(\mathrm{OH})_{2}, \mathrm{SiO}, \mathrm{AFm}$ and AFt (monossulphate/ ettringite) phases. The AM2 mortar presented, apart from the compounds mentioned above, $\mathrm{CaCO}_{3}$. This compound is from the textile residue that is composed essentially of $\mathrm{CaCO}_{3}$ and $\mathrm{Ca}(\mathrm{OH})_{2}$. The reduction in flexion strength of $\mathrm{AM} 1$ mortar, compared to SM mortar, is caused by the polystyrene whereas the lowering mechanical strength of the AM2 is due to both polyurethane and textile residue. Even so, its mechanical strength is acceptable because the flexion strength stress required for the industrial application is $1.0 \mathrm{MPa}$.
\end{abstract}

Keywords: mortar, industrial waste, sink, stainless steel.

Resumo

O objetivo desse trabalho foi estudar as propriedades de argamassas alternativas usadas para reforço de chapas metálicas de pias de cozinha. O desempenho dessas argamassas foi comparado com aquele de uma argamassa básica feita de cimento, areia e água, denominada argamassa padrão (SM). Uma dessas argamassas, denominada argamassa alternativa 2 (AM2), composta de cimento, resíduo, poliuretano, fibras de polipropileno e água, foi desenvolvida recentemente para substituir a atual, chamada argamassa alternativa 1 (AM1), composta de cimento, areia, poliestireno, fibras de polipropileno e água. Essas argamassas foram produzidas e envelhecidas em um quarto à temperatura atmosférica por 7, 14, 28, 60 e 90 dias com ou sem secagem inicial em estufa. Após 90 dias de cura a tensão de resistência à flexão das argamassas SM, AM1 e AM2 foi, respectivamente, de 5,21, 3,84 e 1,42 MPa. Nas argamassas SM e AM1 foram encontradas as fases $\mathrm{C}-\mathrm{S}-\mathrm{H}, \mathrm{Ca}(\mathrm{OH})_{2}, \mathrm{SiO}_{2}, \mathrm{AFm}$ e AFt (monossulfato/etringita). A argamassa AM2 apresentou, além das fases mencionadas acima, $\mathrm{CaCO}_{3}$. Este composto é proveniente do resíduo têxtil que é composto essencialmente de $\mathrm{CaCO}_{3}$ e $\mathrm{Ca}(\mathrm{OH})_{2}$. A diminuição da resistência à flexão da argamassa AM1, comparada com a argamassa SM, é provocada pela presença de poliestireno enquanto que a diminuição da resistência mecânica da argamassa AM2 é devido à presença de poliuretano e resíduo têxtil. Contudo, a resistência mecânica à flexão da argamassa A2 se mantém acima do mínimo exigido pela aplicação industrial (1 MPa).

Palavras-chave: argamassa, resíduo industrial, pia, aço inoxidável.

\section{INTRODUCTION}

Metal sinks are broadly produced with stainless steel sheets. These steel sheets are thin and may easily bend under mechanical forces. Wood or a mortar layer is used to strengthen the steel sink. In the last decade mortars have been used to replace wood. The mortar mixture is poured on the backside of the metal sink. After setting and hardening, the mortar prevents the sink metal sheet from bending.

Since the concern with the cost of raw materials and with the environment, some industries are trying to use industrial waste as raw materials in mortar production. Actually, one of the biggest challenges the mankind needs to face nowadays is how to assure a continuous industrial development and improve the environment. This issue has been discussed in many global summits around the world in order to reduce the amount of industrial wastes. For the time being, political leaders have failed in find an appropriate compromise between industrial development and environmental protection. Despite all the discussion about sustainable development there is a lack of political will to create new regulations about reasonable use of raw materials, recycling and reutilization of wastes. Most of the countries have tough environmental protection laws so that the factories are supposed to adopt suitable treatment and disposal procedures for their industrial wastes. Nevertheless, 
these laws are not enough to preserve the environment and factories' major concern is above all focused in reducing production costs so that they can be more competitive. In an effort to minimize these costs and at the same time protect the environment, many studies have concentrated on assessing the utilization of certain wastes as raw materials in the construction industry [1-4]. Depending upon their chemical composition, these wastes can be incorporated into mortars to partially replace cement and/or aggregate. In a recent study [5], It was fabricated many mortars with the addition of a controlled mixing of industrial wastes in substitution to the fine aggregate normally used in building materials (sand). The purpose of this work was to improve adherence and lightweight of an industrial mortar for sink metal sheet. An optimum mixture containing about $30 \%$ by volume of textile residue was obtained which provided the best compromise between adherence, lightweight, and mechanical resistance required (1.0 MPa minimum). As reported previously [5] this new mortar, named alternative mortar 2 (AM2) is lighter than the current one, named alternative mortar 1 (AM1) by $30 \%$. Following this study we investigated the hydration process and the mechanical, microstructural, physical-chemical, and environmental performance of this mortar (AM2) compared to the industrial current mortar (AM1) and to a reference mortar made of cement, sand and water, named standard mortar (SM). These results are presented and discussed in detail in this work.

\section{MATERIALS AND EXPERIMENTAL PROCEDURE}

\section{CPV ARI RS Portland cement}

With a rapid setting the CPV ARI RS Portland cement is suitable for sink production. This cement, density of $2.98 \mathrm{~g} / \mathrm{cm}^{3}$, is reckoned by its high mechanical strength at the early ages about $27 \mathrm{MPa}$ after one day, i.e. about $50 \%$ of its strength after 28 days - as well as its good resistance to sulphate environments. The chemical composition of the oxides present in the CPV ARI RS Portland cement compounds is $51.08 \%$ $\mathrm{CaO}, 23.77 \% \mathrm{SiO}_{2}, 7.63 \% \mathrm{Al}_{2} \mathrm{O}_{3}, 3.16 \% \mathrm{Fe}_{2} \mathrm{O}_{3}, 5.33 \% \mathrm{MgO}$, $3.64 \% \mathrm{SO}_{3}, 0.17 \% \mathrm{Na}_{2} \mathrm{O}, 1.28 \% \mathrm{~K}_{2} \mathrm{O}, 2.28 \% \mathrm{CO}_{2}$, and $13.44 \%$ of impurities. The four major compounds of a Portland cement are tricalcium silicate $\left(\mathrm{Ca}_{3} \mathrm{SiO}_{5}\right)$, dicalcium silicate $\left(\mathrm{Ca}_{2} \mathrm{SiO}_{4}\right)$, tricalcium aluminate $\left(\mathrm{Ca}_{3} \mathrm{Al}_{2} \mathrm{O}_{6}\right)$ and tetracalcium aluminoferrite $\left(\mathrm{Ca}_{2} \mathrm{AlFeO}_{5}\right)$. They are also known as alite, $3 \mathrm{CaO} . \mathrm{SiO}_{2}$ (noted $\mathrm{C}_{3} \mathrm{~S}$ ), belite, $2 \mathrm{CaO} . \mathrm{SiO}_{2}\left(\mathrm{C}_{2} \mathrm{~S}\right)$, aluminate phase, $3 \mathrm{CaO} \cdot \mathrm{Al}_{2} \mathrm{O}_{3}\left(\mathrm{C}_{3} \mathrm{~A}\right)$, and ferrite phase, $4 \mathrm{CaO} \cdot \mathrm{Al}_{2} \mathrm{O}_{3} \cdot \mathrm{Fe}_{2} \mathrm{O}_{3}$ $\left(\mathrm{C}_{4} \mathrm{AF}\right)$, respectively. Alite is the most important constituent of all normal Porland cement clinkers, of which it constitutes $50-70 \%$. Belite constitutes 15-30\%, aluminate phase constitutes $5-10 \%$ and ferrite phase constitutes $5-15 \%$ of normal Porland cement clinkers [6]. Several other phases, such as gypsum, alkali sulphates and calcium oxide (free lime), are normally present in minor amounts. The gypsum controls the

Table I - Density and granulation size distribution of the sand and of the alternative materials, according to the NBR 77211 code.

[Tabela I - Densidade e distribuição granulométrica da areia e dos materiais alternativos de acordo com a norma NBR 77211.]

\begin{tabular}{|c|c|c|c|c|c|}
\hline \multirow{3}{*}{$\begin{array}{c}\text { Sieve } \\
\text { mesh } \\
\text { size }(\mathrm{mm})\end{array}$} & \multicolumn{5}{|c|}{ Mass retained on the sieve $(\%)$} \\
\hline & Sand & Textile & Polyurethane & Polystyrene & Polypropylene \\
\hline & & residue & & & fibers \\
\hline 2.400 & 0.00 & - & - & Uniform material & \\
\hline 1.200 & 0.35 & - & - & with approximately & \\
\hline 0.850 & - & 50.50 & 72.47 & $4.8 \mathrm{~mm}$ in diameter & \\
\hline 0.600 & 8.15 & 10.80 & 12.19 & Approximately & \\
\hline 0.420 & - & 10.40 & 9.31 & $40 \mathrm{~mm}$ long & \\
\hline 0.300 & 25.65 & 8.00 & 1.46 & & \\
\hline 0.240 & - & 9.20 & 2.30 & & \\
\hline 0.150 & 49.50 & 3.90 & 0.90 & & \\
\hline 0.106 & - & 3,00 & 0.62 & & \\
\hline 0.075 & - & 1.90 & 0.48 & & \\
\hline 0.053 & - & 1.20 & 0.14 & & \\
\hline Dish & 16.35 & 0.80 & 0.14 & & \\
\hline $\begin{array}{l}\text { Density } \\
\left(\mathrm{g} / \mathrm{cm}^{3}\right)\end{array}$ & 1.60 & 0.60 & 0.043 & 0.008 & - \\
\hline
\end{tabular}


rate of set and may be partly replaced by other calcium sulphate-containing material at the grinding stage of the clinker. The heat produced on grinding can cause partial conversion of the gypsum into hemihydrate $\left(2 \mathrm{CaSO}_{4} \cdot \mathrm{H}_{2} \mathrm{O}\right)$ or $\gamma-\mathrm{CaSO}_{4}$. Storage of the cement can result on the formation of syngenite (reaction of gypsum and potassium sulphate), calcite due to carbonation during milling or storage, and normal hydration products [6].

\section{Sand and alternative materials}

The sand (aggregate) used in this work originates from sedimentary layers formed in riverbeds and consists basically of $98 \%$ of silica and $2 \%$ of impurities. The alternative materials (textile residue, polyurethane, polystyrene, and polypropylene fibers) were used essentially to improve lightweight and therefore present low density. The polypropylene fibers were also used to improve mechanical strength. Table I presents the granulometric distribution and the density of the sand and of the alternative materials used in this study. Amongst the alternative materials, the textile residue is an industrial waste from a local textile industry. The textile sludge coming from its waste treatment center goes through a press-filter to take out the exceeding water, followed by drying in a rotary furnace at approximately 220 ${ }^{\circ} \mathrm{C}$. This dried material, greenish-black in color, consists of small agglomerates containing mainly calcium in its chemical composition, although $\mathrm{S}, \mathrm{Si}, \mathrm{Al}, \mathrm{Mg}$, and Fe are also present in smaller amounts.

Of particular note from Table I was the difference between sand and alternative materials granulation size. Contrary to the sand, the textile residue and the polyurethane present a larger granulation size. The granulometric distribution shows that $92.8 \%$ of the textile residue and $98.6 \%$ of the polyurethane present granulation size upper $0.15 \mathrm{~mm}$ whereas $83.6 \%$ of the sand contains granulation size upper $0.15 \mathrm{~mm}$. On the other hand, the alternative materials present a far lower density.

\section{Production of mortars}

The materials used to produce the mortars were dried 24 hours at $110{ }^{\circ} \mathrm{C}$ and then mixed with water during 3 minutes using a mechanical mortar-mixer of 5 liters capacity, followed by molding into $150 \mathrm{~mm}$ x $100 \mathrm{~mm}$ x $30 \mathrm{~mm}$ molds. Table II lists the mixtures used in the preparation of the mortars and the water/cement ratio obtained through the flow-table test according to the Brazilian NBR 7215 code. The water/cement ratio is considered appropriate when the flow-table factor is situated between $210 \mathrm{~mm}$ and $220 \mathrm{~mm}$. For each mixture was produced 16 samples which were aged in two different aging processes: half of them were removed from the molds after 24 hours and half dried 10 hours at $50{ }^{\circ} \mathrm{C}$ and afterward removed from the molds. The samples removed from the molds were then aged in a room in atmospheric environment for 7, 14, 28, 60 , and 90 days to achieve the late period of hydration. The standard mortar samples were only aged in atmospheric environment, i.e. without initial drying in furnace. Upon completion of the aging process, the samples were subjected to mechanical test.

\section{Characterization of the mortars}

The mortar samples were subjected to flexion mechanical tests at $1 \mathrm{~mm} / \mathrm{s}$. Fragments of the samples obtained from the mechanical tests were analyzed by scanning electron microscope (SEM) after being dried in a drying room for 24 hours at $100{ }^{\circ} \mathrm{C}$. The samples were also characterized by differential thermal analysis (DTA), thermogravimetry (TG), $\mathrm{X}$-ray diffraction (XRD), and leaching and solubilization tests performed by calorimetry and atomic absorption. The later was carried out according to the Brazilian NBR 10004 code. The mechanical performance of the AM1 and AM2 alternative mortars was also evaluated by an accelerated aging test through drying and wetting cyclic test according to the Brazilian NBR 13554 code. Forty eight mortar samples of each mixture were

Table II - Amount of materials used to produce the mortars.

[Tabela II - Quantidade de materiais usados para fabricar as argamassas.]

\begin{tabular}{c|c|c|c|c|c|c}
\hline \multirow{2}{*}{ Materials } & \multicolumn{2}{|c|}{$\begin{array}{c}\text { Standard Mortar } \\
(\mathrm{SM})\end{array}$} & \multicolumn{2}{c|}{$\begin{array}{c}\text { Alternative mortar 1 } \\
(\mathrm{AM} 1)\end{array}$} & \multicolumn{2}{c}{$\begin{array}{c}\text { Alternative mortar 2 } \\
\text { (AM2) }\end{array}$} \\
\hline Cement & $1000 \mathrm{~g}$ & $25.00 \%$ & $1000 \mathrm{~g}$ & $24.53 \%$ & $1000 \mathrm{~g}$ & $66.22 \%$ \\
\hline Sand & $3000 \mathrm{~g}$ & $75.00 \%$ & $3060 \mathrm{~g}$ & $75.07 \%$ & - & - \\
\hline Polystyrene & - & & $7.17 \mathrm{~g}$ & $0.18 \%$ & - & - \\
\hline Polyurethane & - & & - & - & $72.11 \mathrm{~g}$ & $4.78 \%$ \\
\hline Polypropylene Fiber & - & & $8.96 \mathrm{~g}$ & $0.22 \%$ & $4.15 \mathrm{~g}$ & $0.27 \%$ \\
\hline Textile residue & - & - & & $433.85 \mathrm{~g}$ & $28.73 \%$ \\
\hline Water/cement ratio & \multicolumn{2}{|c|}{0.750} & \multicolumn{2}{|c|}{0.817} & & 0.862 \\
\hline Flow-table factor (mm) & \multicolumn{2}{|c|}{220} & 215 & 215 \\
\hline
\end{tabular}


then produced, molding them into $150 \mathrm{~mm} \times 100 \mathrm{~mm} \times 30$ mm molds. After 24 hours the samples were removed from the molds and aged in a room in atmospheric environment for 28 days. Shortly after, the drying and wetting cyclic test was performed as follows: (1) mechanical test on 6 samples of either AM1 or AM2 mortars, (2) wetting period of 24 hours in alkaline water, (3) and drying period of 7 days at $71{ }^{\circ} \mathrm{C}$.

\section{RESULTS}

\section{Flexion test}

The flexion mechanical test was performed by three points contact on the standard mortar (SM), and on the AM1 and AM2 alternative mortars obtained by both hydration process, i.e. without (AM1A or A2MA) or with initial drying in furnace (AM1F or AM2F), respectively. Fig. 1 illustrates the results of these tests where the values indicate the average flexion strength stress of 8 samples.

It can be observed that the mechanical strength depends on the mixtures of the mortars, on the aging time, and on the hydration process of the samples. Contrary to the AM2A, the flexion strength stress of the SM and AM1A mortars increases with the aging time. The stress variation is more remarkable up to 28 days from where the values continue to increase slowly, tending to a flexion strength steady state after 90 days. The flexion strength stress of the AM2A decreases continuously reaching its steady state after 28 days. The mechanical strength of the SM, AM1A, and AM2A mortars after 90 days of aging time is respectively 5.21, 3.84, and $1.42 \mathrm{MPa}$. Therefore, the alternative materials decrease the flexion strength stress of the mortars compared to the standard mortar (SM). Nevertheless,

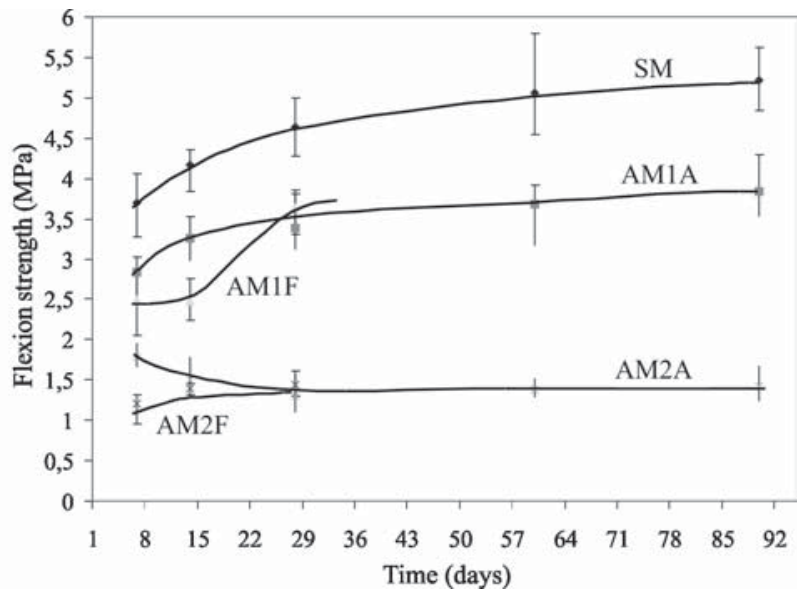

Figure 1: Average flexion strength stress of the standard mortar (SM), aged in atmospheric environment without initial drying, and of the alternative mortars aged in atmospheric environment without initial drying (AM1A or AM2A) or aged in atmospheric environment with initial drying (AM1F or AM2F).

[Figura 1: Tensão de resistência à flexão media da argamassa padrão (SM), envelhecida em meio atmosférico sem secagem inicial, $e$ das argamassas alternativas envelhecidas em meio atmosférico sem secagem inicial (AM1A ou AM2A) ou envelhecidas em meio atmosférico com secagem inicial (AMIF ou AM2F).] the alternative mortars present a flexion mechanical strength superior to $1 \mathrm{MPa}$ value required upon completion of 90-day hydration period. Another important point to be observed is the behavior in mechanical strength of the alternative mortars aged with initial drying in furnace (AM1F and AM2F). The mechanical resistance after 7 and 14 days of these mortars is lower than that of the same mortars but aged without initial drying in furnace. Although these values are lower in the beginning, they increase and achieve the same values of the AM1A and AM2A mortars after 28 days of aging time.

\section{$X$-ray diffraction and thermal analysis}

X-ray diffraction analyses performed on the standard mortar (SM) allowed us to identify the presence of $\mathrm{SiO}_{2}$, essentially from the sand, $\mathrm{Ca}(\mathrm{OH})_{2}$ (calcium hydroxide) and peaks corresponding to unreacted $\mathrm{C}_{3} \mathrm{~S}$ (alite) and $\mathrm{C}_{2} \mathrm{~S}$ (belite) phases. Many peaks of $\mathrm{SiO}_{2}$ and of alite and belite overlapped ones of other phases making difficult the analysis, specially the identification of calcium silicate hydrate. Evidence from XRD, DTA and other techniques [6] have indicated that the hydration products of alite and belite are calcium hydroxide $(\mathrm{CH})$ and a nearly amorphous calcium silicate hydrate having the properties of a rigid gel. The calcium silicate hydrate formed is a particular variety of $\mathrm{C}-\mathrm{S}-\mathrm{H}$, which is a generic name for any amorphous or poorly crystalline calcium silicate hydrate. We know that C-S-H phases are barely distinguishable by XRD, but taking into account the amount of C-S-H likely to be present, this method suggests that these phases are poorly crystalline. According to Mehta [7], a Portland cement paste contains $50-60 \%$ of calcium silicate hydrate (C-S-H phases) and $20-25 \%$ of calcium hydroxide $(\mathrm{CH})$. Most of them, poorly crystalline and also known as C-S-H gel, cannot be properly characterized by XRD. C-S-H phases are not only the major products formed during the hydration process, but also those, amongst the hydration products, that present the highest mechanical strength [8].

The hydration process of the alternative mortars was also studied by X-ray diffraction after 7, 14, and 28 days of curing time. This study revels the presence of alite, belite, $\mathrm{Ca}(\mathrm{OH})_{2}$, and $\mathrm{SiO}_{2}$ on AM1A samples. Similar spectrum was found on the AM1F mortar where no significant difference on the hydration process was observed between 7 and 28 days of aging time compared to the AM1A mortar. However, an evolution in the peaks regarding the alite and belite compounds was observed on the XRD spectrum of these mortars. Analyzing the peaks intensity we realized that they decline with the age, showing the hydration of alite and belite. This phenomenon was already expected because completion of hydration occurs after about one year in moist conditions of at least $80 \%$ relative humidity. The hydration products formed on the AM2A and AM2F samples were the same as that found on the AM1 mortar. Nevertheless, on the X-ray diffraction pattern of the alternative mortars 2 we have a predominant peak of $\mathrm{CaCO}_{3}$. Analysis by XRD, DTA and TG carried out on the textile residue led us to the characterization of its main compounds. As received from the textile industry, the residue is basically composed of calcium 


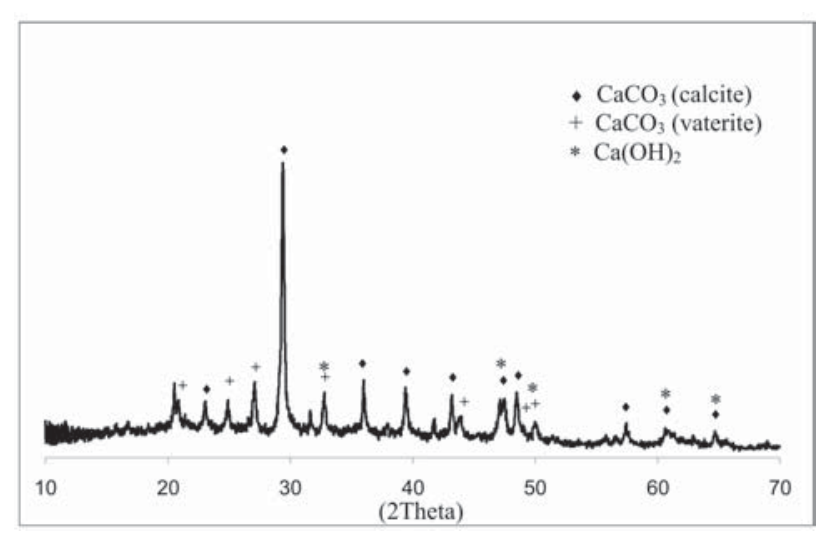

Figure 2: X-ray diffraction pattern showing the main compounds present in the textile residue as received from the textile industry. [Figura 2: Difratograma de raios X mostrando os principais compostos presentes no resíduo têxtil bruto.]

carbonate, $\mathrm{CaCO}_{3}$ (calcite) and $\mathrm{CaCO}_{3}$ (vaterite), containing also calcium hydroxide, $\mathrm{Ca}(\mathrm{OH})_{2}$, in smaller amounts (Fig. 2). At approximately $350{ }^{\circ} \mathrm{C}$ the calcium hydroxide turns into $\mathrm{CaO}$ according to the chemical reaction, $\mathrm{Ca}(\mathrm{OH})_{2}=\mathrm{CaO}+\mathrm{H}_{2} \mathrm{O}$, and at approximately $770{ }^{\circ} \mathrm{C}$ all the calcium carbonate is transformed in calcium oxide, $\mathrm{CaCO}_{3}=\mathrm{CaO}+\mathrm{CO}_{2}$. Therefore, It is more likely that the calcium carbonate detected by XRD on the AM2A and AM2F mortars is from the textile residue. The XRD spectrums of these two mortars were also similar.

DTA curves for pastes of the CPV ARI RS Portland cement at age up to 7 days have shown that the peak at $135-140{ }^{\circ} \mathrm{C}$ is due to ettringite, the peak at $115-125{ }^{\circ} \mathrm{C}$ is due to $\mathrm{C}-\mathrm{S}-\mathrm{H}$, or cement gel, the peak at $185-200{ }^{\circ} \mathrm{C}$ is due to aluminate and ferrite hydrate phases, and that at $530-550{ }^{\circ} \mathrm{C}$ to $\mathrm{CH}$. DTA studies for pastes of cement mixed with $30 \%$ of residue, carried out in the same conditions of the cement pastes, led fairly to a similar result. Apart from the phases above identified it was found a peak of $\mathrm{CaCO}_{3}$.

\section{Microstructural observations}

The samples were characterized on the fracture crosssection, where good adherence of the cement paste on the aggregate (sand) and a few porosity were observed (Fig. 3). Fig. 4 illustrates the good nucleation and growth of ettringite crystals, revealing a normal hydration process during the 28 day aging period. The ettringite crystals are also known as anhydrite crystals and are formed by precipitation of aqueous ions of aluminum, sulfur, and calcium, known as $\mathrm{C}_{6} \mathrm{AS}_{3} \mathrm{H}_{32}$, hydrated calcium aluminum sulfate hydroxide.

The AM1 mortar displayed a similar microstructure of the cement paste compared to the SM mortar showing that these two mortars have a similar hydration. However, The AM1 mortar contains polystyrene and polypropylene fibers in its composition, as indicated in Figs. 5 and 6. Good adherence of the cement paste/polystyrene interface leads to polystyrene's bulk fracture rather then interface rupture when the AM1 material is subjected to mechanical forces. On the other hand, the polypropylene fibers has a poor adherence with the cement paste, but its length is enough to assure an anchorage effect in the cement paste leading to fibers rupture in the fracture crosssection of the mortar.

The AM2 mortars stood out from the other mortars by presenting smaller amounts of ettringite and more porosity (Fig. 7). The hydraulic binder of this mortar is supposed to be a mixture of cement

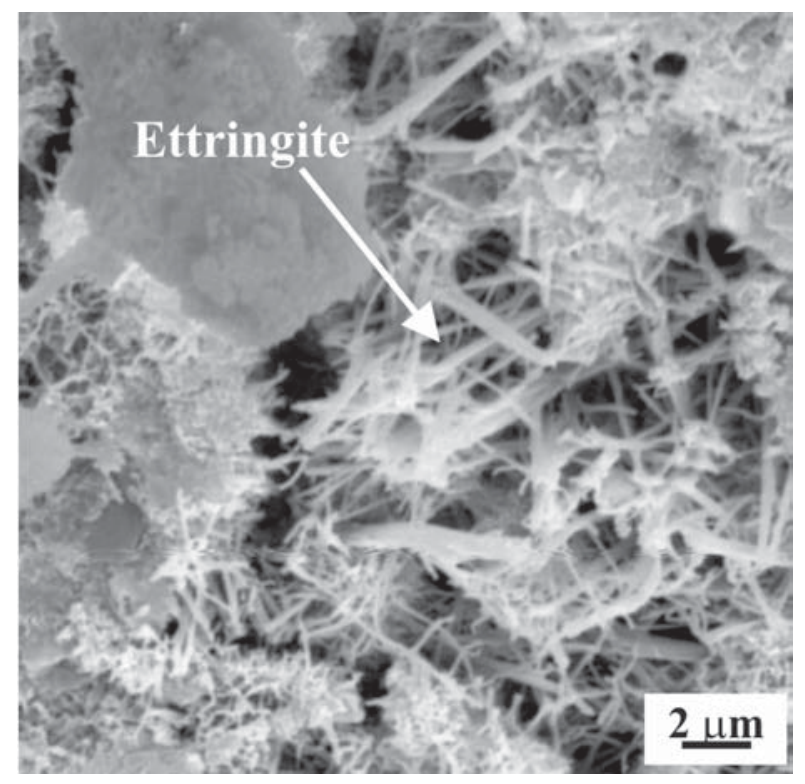

Figure 3: SEM micrograph of ettringite crystals in SM mortar after 14-day aging period.

[Figura 3: Micrografia MEV dos cristais de etringita na argamassa SM após 14 dias de cura.]

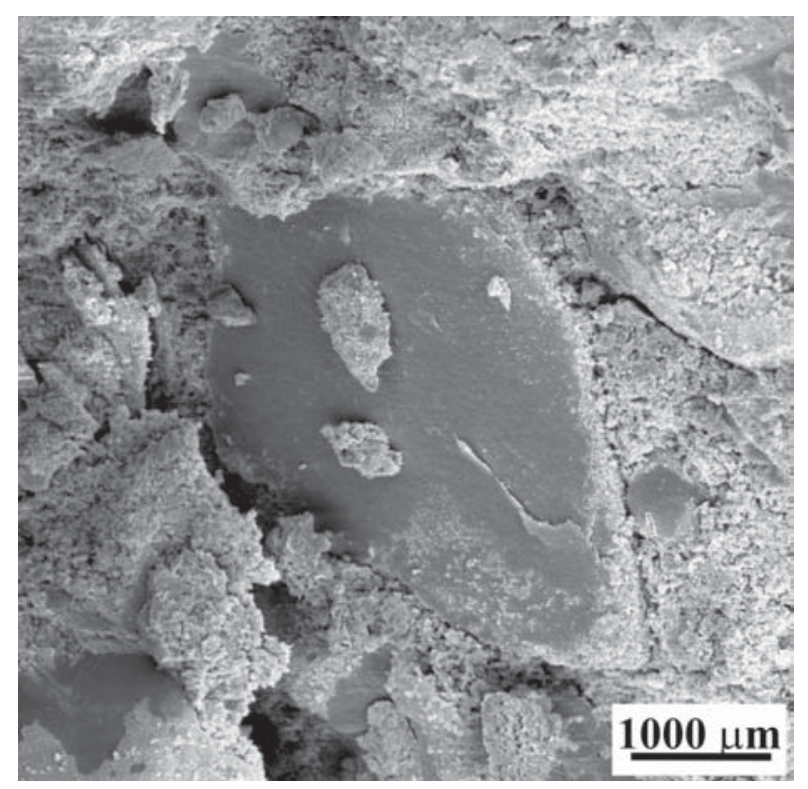

Figure 4: SEM micrograph of the SM mortar's cement paste/ aggregate interface after 14-day aging period.

[Figura 4: Micrografia MEV da interface pasta de cimento/agregado da argamassa SM após 14 dias de cura.] 
and textile residue. Actually, the residue compounds interfere in the hydration process by reacting with the cement compounds. The bubbling out phenomenon observed during the manufacture of the mortars when the cement and the residue were mixed with water backs up this statement. This phenomenon also might explain the excess of porosity formed in the alternative mortars 2. Similar comportment to the polystyrene in alternative mortar 1 (AM1) was also observed with the polyurethane in alternative mortar 2 (AM2).

\section{Leaching and solubilization tests}

Leaching and solubilization tests were carried out following the Brazilian NBR 10004 code. The chemical elements chosen for these tests are those that represent the highest risk to fauna and flora. They are used to evaluate the environment behavior of waste materials. According to these tests the waste materials can be classified as hazardous (class I), harmless but non-inert (class II), and harmless and inert (class III). The leaching and solubilization tests were performed on the cement, the textile residue, and the AM2 mortar, which contains textile residue, and compared to the SM mortar after 28-day aging period. Tables III and IV show the chemical analyses of the leached and solubilized materials, respectively. It was found that, in every leached sample, the chemical elements analyzed all displayed concentrations below the maximum limits established by the NBR 10004 code. On the other hand, the solubilization test indicates that all samples can be classified as non-inert class II materials considering that some chemical elements presented concentration over the maximum limits established by the NBR 10004 code. An analysis of the SM and AM2 mortars shows that only aluminum, cadmium and lead presented concentration beyond the maximum limits.

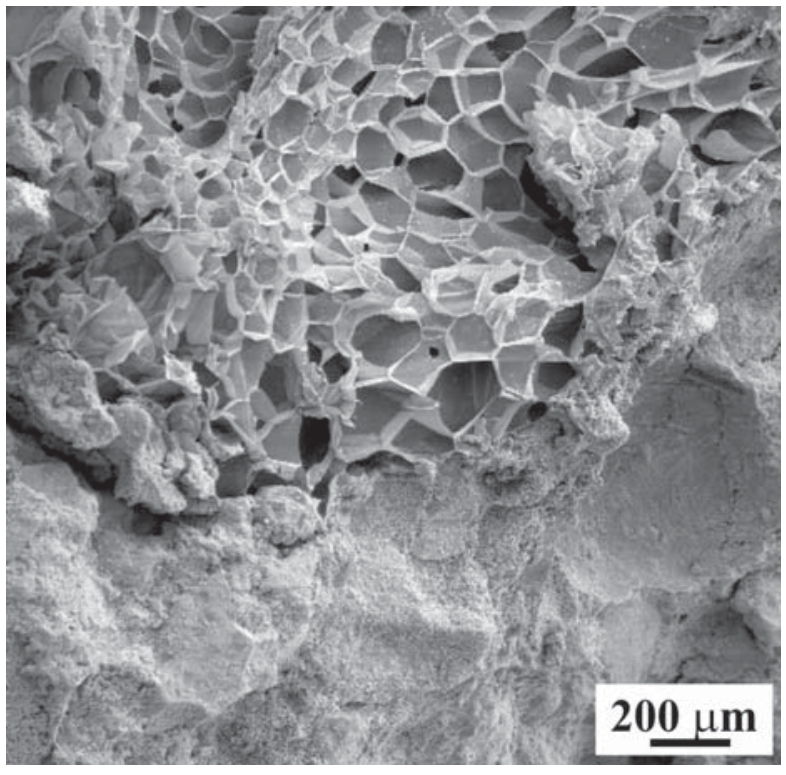

Figure 5: SEM micrograph of the AM1F mortar after 7-day aging period showing polystyrene's bulk fracture.

[Figura 5: Micrografia MEV da argamassa AM1F após 7 dias de cura mostrando a fratura do poliestireno.]

Amongst these chemical elements only the cadmium and lead are hazardous to fauna and flora. The aluminum is a chemical element strongly electronegative and it is unlikely that it can be found in ionic state, and therefore, it can be considered harmless to flora and fauna. Regarding the lead and the cadmium elements, further chemical analyses would be required to reach a more conclusive result. On one hand, lead

Table III - Chemical analysis of the leached extracts. QL = quantification limit.

[Tabela III - Análise química dos extratos lixiviados. $Q L=$ limite de quantificação.]

\begin{tabular}{cccccc}
\hline Element & $\begin{array}{c}\text { Maximum } \\
\text { Limit NBR } \\
10004(\mathrm{mg} / \mathrm{L})\end{array}$ & $\begin{array}{c}\text { Textile residue } \\
(\mathrm{mg} / \mathrm{L})\end{array}$ & $\begin{array}{c}\text { Cement } \\
(\mathrm{mg} / \mathrm{L})\end{array}$ & $\begin{array}{c}\mathrm{SM} \\
(\mathrm{mg} / \mathrm{L})\end{array}$ & $\begin{array}{c}\text { AM2 } \\
(\mathrm{mg} / \mathrm{L})\end{array}$ \\
\hline Arseno group & 5.0 & 0.005 & $<\mathrm{QL}$ & $<\mathrm{QL}$ & $<\mathrm{QL}$ \\
\hline Barium & 100 & 0.98 & $<\mathrm{QL}$ & $<\mathrm{QL}$ & $<\mathrm{QL}$ \\
\hline Cadmium & 0.5 & 0.03 & 0.04 & $<\mathrm{QL}$ & $<\mathrm{QL}$ \\
\hline Lead & 5.0 & 0.45 & $<\mathrm{QL}$ & $<\mathrm{QL}$ & $<\mathrm{QL}$ \\
\hline Chromium & 5.0 & $<\mathrm{QL}$ & $<\mathrm{QL}$ & $<\mathrm{QL}$ & $<\mathrm{QL}$ \\
\hline Fluorides & 150 & 0.59 & 1.16 & 0.44 & 0.42 \\
\hline Mercury & 0.1 & 0.0026 & $<\mathrm{QL}$ & $<\mathrm{QL}$ & $<\mathrm{QL}$ \\
\hline Nickel & - & $<\mathrm{QL}$ & 0.20 & $<\mathrm{QL}$ & $<\mathrm{QL}$ \\
\hline Silver & 5.0 & 0.05 & $<\mathrm{QL}$ & $<\mathrm{QL}$ & $<\mathrm{QL}$ \\
\hline Selenium & 1.0 & $<\mathrm{QL}$ & $<\mathrm{QL}$ & $<\mathrm{QL}$ & $<\mathrm{QL}$ \\
\hline Zinc & - & - & 0.03 & 0.04 & 0.06 \\
\hline
\end{tabular}


Table IV - Chemical analysis of the solubilized extracts. ND = non-detected. [Tabela IV - Análise química dos extratos solubilizados. $N D=$ não detectado.]

\begin{tabular}{cccccc}
\hline Element & $\begin{array}{c}\text { Maximum Limit } \\
\text { NBR } 10004(\mathrm{mg} / \mathrm{L})\end{array}$ & $\begin{array}{c}\text { Textile residue } \\
(\mathrm{mg} / \mathrm{L})\end{array}$ & $\begin{array}{c}\text { Cement } \\
(\mathrm{mg} / \mathrm{L})\end{array}$ & $\begin{array}{c}\text { SM } \\
(\mathrm{mg} / \mathrm{L})\end{array}$ & $\begin{array}{c}\text { AM2 } \\
(\mathrm{mg} / \mathrm{L})\end{array}$ \\
\hline Aluminum & 0.2 & 2.93 & $<\mathrm{QL}$ & 0.5 & 1.44 \\
\hline Arseno group & 0.05 & N.D. & $<\mathrm{QL}$ & $<\mathrm{QL}$ & $<\mathrm{QL}$ \\
\hline Barium & 1.0 & 0.24 & $<\mathrm{QL}$ & $<\mathrm{QL}$ & $<\mathrm{QL}$ \\
\hline Cadmium & 0.005 & 0.02 & 0.02 & $<\mathrm{QL}$ & 0.01 \\
\hline Lead & 0.05 & 0.16 & 0.17 & 0.07 & 0.09 \\
\hline Cyanide & 0.1 & N.D. & $<\mathrm{QL}$ & $<\mathrm{QL}$ & $<\mathrm{QL}$ \\
\hline Chlorides & 250.0 & 51 & 69.98 & 83.98 & 83.98 \\
\hline Copper & 1.0 & 0.36 & $<\mathrm{QL}$ & $<\mathrm{QL}$ & 0.40 \\
\hline Chromium & 0.05 & N.D. & $<\mathrm{QL}$ & $<\mathrm{QL}$ & $<\mathrm{QL}$ \\
\hline Hardness & 500.0 & $1,778.00$ & $2,000.00$ & 246.00 & 700.00 \\
\hline Phenols & 0.001 & N.D. & $<\mathrm{QL}$ & $<\mathrm{QL}$ & $<\mathrm{QL}$ \\
\hline Iron & 0.3 & 0.23 & 0.25 & 0.22 & 0.15 \\
\hline Fluorides & 1.5 & 0.22 & 0.46 & 0.41 & 0.94 \\
\hline Manganese & 0.1 & 0.02 & $<\mathrm{QL}$ & $<\mathrm{QL}$ & $<\mathrm{QL}$ \\
\hline Mercury & 0.001 & N.D. & $<\mathrm{QL}$ & $<\mathrm{QL}$ & $<\mathrm{QL}$ \\
\hline Nitrates & 10.0 & 0.8 & $<\mathrm{QL}$ & $<\mathrm{QL}$ & $<\mathrm{QL}$ \\
\hline Silver & 0.05 & 0.03 & $<\mathrm{QL}$ & $<\mathrm{QL}$ & $<\mathrm{QL}$ \\
\hline Selenium & 0.01 & N.D. & $<\mathrm{QL}$ & $<\mathrm{QL}$ & $<\mathrm{QL}$ \\
\hline Sodium & 200.0 & 234 & 46.60 & 16.60 & 33.70 \\
\hline Sulfates & 400.0 & 170 & 589 & 32.87 & 24.55 \\
\hline Surfactants & 0.2 & 0.32 & $<\mathrm{QL}$ & $<\mathrm{QL}$ & $<\mathrm{QL}$ \\
\hline Zinc & 5.0 & N.D. & 0.02 & 0.01 & 0.01 \\
\hline
\end{tabular}

concentration in mortars is very close to its maximum limit established, and on the other hand, lead and cadmium concentration in cement should be below the maximum limits established by the NBR 10004 code.

\section{Wetting and drying cyclic test}

The mechanical stability of the alternative mortars subjected to a hostile environment was evaluated by wetting and drying cyclic test. Fig. 8 shows the average flexion strength of the alternative mortars (AM1 and AM2) where no significant difference in strength values is observed after each cycle. The flexion strength tends to decrease slightly in the firsts cycles stabilizing at approximately 1.0 MPa after the fifth cycle for the AM2 mortar while for the AM1 mortar the flexion strength remains steady at approximately $3.5 \mathrm{MPa}$. A comparison analyses between the cyclic test and the mechanical test carried out on the samples aged in room in atmospheric environment revels a similar behavior in the flexion strength stress. Our conclusion regarding the cyclic test is that the wetting and drying alternated periods do not affect the mechanical stability.

\section{DISCUSSION}

The investigation reported on herein demonstrated that the mortars' properties depend on the hydration process, on the mixtures, and especially on the products formed by the hydraulic binder during the hydration. Hydration products of aluminate and ferrite phases were not identified by XRD on any material investigated in this work. Hydration of aluminate and ferrite phases yields the so-colled AFm $\left(\mathrm{Al}_{2} \mathrm{O}_{3}-\mathrm{Fe}_{2} \mathrm{O}_{3}\right.$ mono) phases and $\mathrm{AFt}\left(\mathrm{Al}_{2} \mathrm{O}_{3}-\mathrm{Fe}_{2} \mathrm{O}_{3}\right.$-tri) phases [6]. AFm phases are formed under broadly similar conditions to $\mathrm{AFt}$ phases but they have different structures. Under favorable conditions, AFm phases form platey, hexagonal crystals with excellent cleavage (0001) [6]. Some of the AFm phase formed 


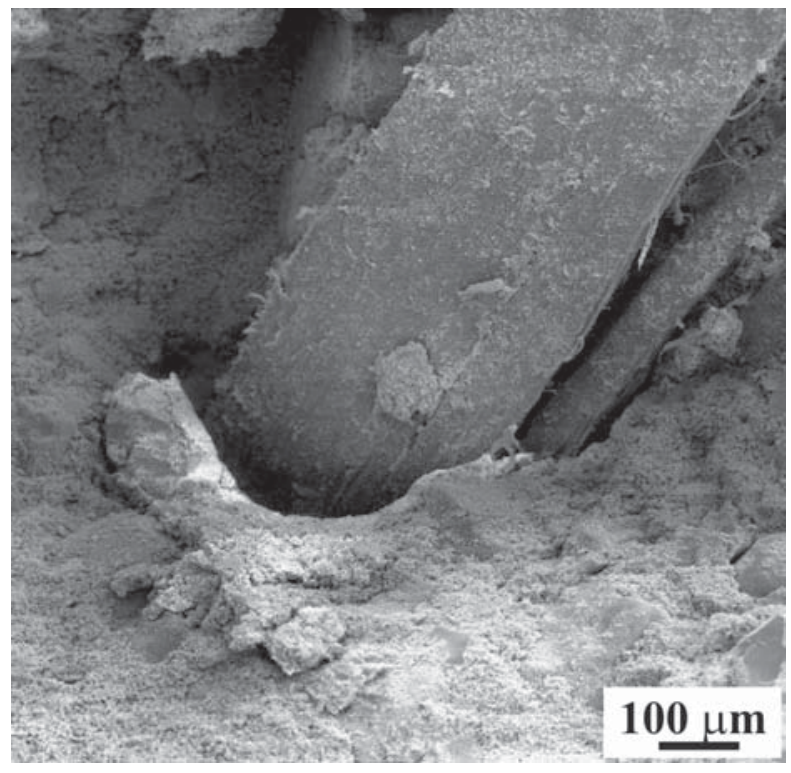

Figure 6: SEM micrograph of the AM1F mortar after 14-day aging period showing the anchorage effect of the polypropylene fibers.

[Figura 6: Micrografia MEV da argamassa AM1F após 14 dias de cura mostrando o efeito da ancoragem das fibras de poliestireno.]

in Portland cement pastes is of this type, but much is poorly crystalline and intimately mixed with $\mathrm{C}-\mathrm{S}-\mathrm{H}$. AFm have the general formula $\mathrm{C}_{3}(\mathrm{~A}, \mathrm{~F}) \mathrm{CaX}_{2} \cdot \mathrm{yH}_{2} \mathrm{O}$ (or $\mathrm{C}_{4}(\mathrm{~A}, \mathrm{~F}) \mathrm{X}_{2} \cdot \mathrm{yH}_{2} \mathrm{O}$ ), where $\mathrm{X}$ denotes one formula unit of a singly charged anion, or half a formula unit of a doubly charged anion. The term 'mono' relates to the single formula unit of $\mathrm{CaX}_{2}$. Many different anions can serve as $\mathrm{X}$, of which the most important are $\mathrm{OH}^{-}, \mathrm{SO}_{4}{ }^{2-}$, and $\mathrm{CO}_{3}{ }^{2-}$ [6]. AFt phases form hexagonal prismatic or acicular crystals [6]. They have the general constitutional formula $\mathrm{C}_{3}(\mathrm{~A}, \mathrm{~F}) 3 \mathrm{CX} . \mathrm{yH}_{2} \mathrm{O}$ (or $\left.\mathrm{C}_{6}(\mathrm{~A}, \mathrm{~F}) \mathrm{X}_{3} \cdot \mathrm{yH}_{2} \mathrm{O}\right)$, where $\mathrm{X}$ represents one formula unit of a doubly charged, or, with reservations, two formula units of a singly charged anion. The term 'tri' refers to the three units of CX. The most important AFt phase is ettringite. It forms on cement pastes in the early ages (after about $15 \mathrm{~min}$ ) and can further be replaced by monossulphate depending on the amount of $\mathrm{SO}_{4}^{2-}$ ions in solution, though some ettringite can persist until the final period of hydration. Since the little amount of ettringite present in the mortars, we could not identify it by XRD but so by SEM. Taking into account that SM and AM1A mortars exhibited a normal hydration, Afm phase is also probably present in these mortars but in small concentration. DTA evidences from the cement pastes indicate that all the hydration products of a normal Portland cement are present in the mortars, viz $\mathrm{CH}, \mathrm{C}-\mathrm{S}-\mathrm{H}, \mathrm{AFm}$ and AFt phases.

The mechanical behavior observed on SM and AM1A mortars is also characteristic of a normal hydration. The mechanical strength increases faster in the early ages tending to a stationary strength after 90-day aging period. Although the mechanical strength evolution on AM1A mortar is similar to that of SM mortar, its average mechanical strength values are lower than those of SM mortar. This difference can be attributed to the polystyrene. According to the observations, the polystyrene has a very low mechanical strength, disrupting readily in mortar when the material is subjected to flexion forces. It means the polystyrene's mechanical strength is so poor that it behaves like a defect in mortar, similarly to a cavity. The polystyrene as well as the polypropylene fibers are chemically inert and do not interfere in the hydration process. Apart from lightweight, the polypropylene fibers provide slightly higher flexion strength in mortar compared to the same mortar without polypropylene fibers [5].

The AM2A mortar stands out from those above mentioned by its great amount of $\mathrm{CaCO}_{3}$. As reported previously, the textile residue, formed essentially of $\mathrm{CaCO}_{3}$ and $\mathrm{Ca}(\mathrm{OH})_{2}$, reacts chemically with the cement when both are mixed with water. As the $\mathrm{CaCO}_{3}$ concentration is very high only one part of it can be dissolved and the other stay closed into the hydraulic binder (cement gel). The bubbling out phenomenon observed during the manufacture of the mortars occurs due to decarbonation according to the reactions:

$$
\begin{aligned}
& 2 \mathrm{CaCO}_{3}+2 \mathrm{H}_{2} \mathrm{O}=\mathrm{Ca}(\mathrm{OH})_{2}+\mathrm{Ca}\left(\mathrm{HCO}_{3}\right)_{2} \\
& \mathrm{Ca}\left(\mathrm{HCO}_{3}\right)_{2}+2 \mathrm{H}_{2} \mathrm{O}=\mathrm{Ca}(\mathrm{OH})_{2}+2 \mathrm{H}_{2} \mathrm{CO}_{3} \\
& 2 \mathrm{H}_{2} \mathrm{CO}_{3}=2 \mathrm{H}_{2} \mathrm{O}+2 \mathrm{CO}_{2}
\end{aligned}
$$

The residue increases dramatically the amount of calcium in the paste influencing the composition of the hydration products. Greater amounts of $\mathrm{CH}$ as well as $\mathrm{C}-\mathrm{S}-\mathrm{H}$ high in calcium due to the increase of $\mathrm{Ca} / \mathrm{Si}$ ratio are the major effects. AFm and AFt phases higher in calcium are also probably

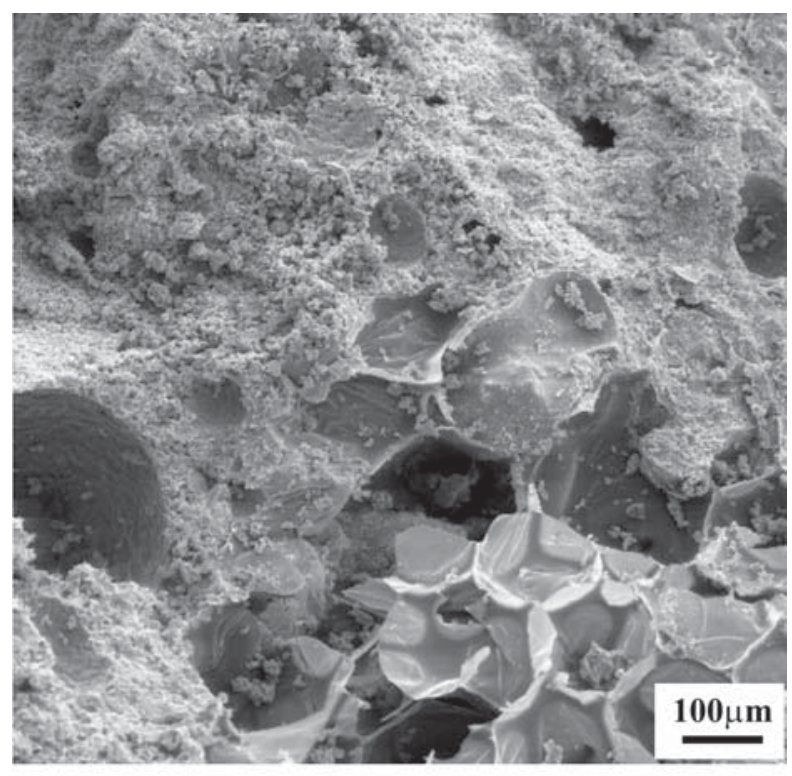

Figure 7: SEM micrograph of the AM2A mortar showing porosity and polystyrene/(cement + residue) paste interface after 28-day aging period.

[Figura 7: Micrografia MEV da argamassa AM2A mostrando a porosidade e a interface poliestireno/pasta de (cimento + resíduo) após 28 dias de cura.] 


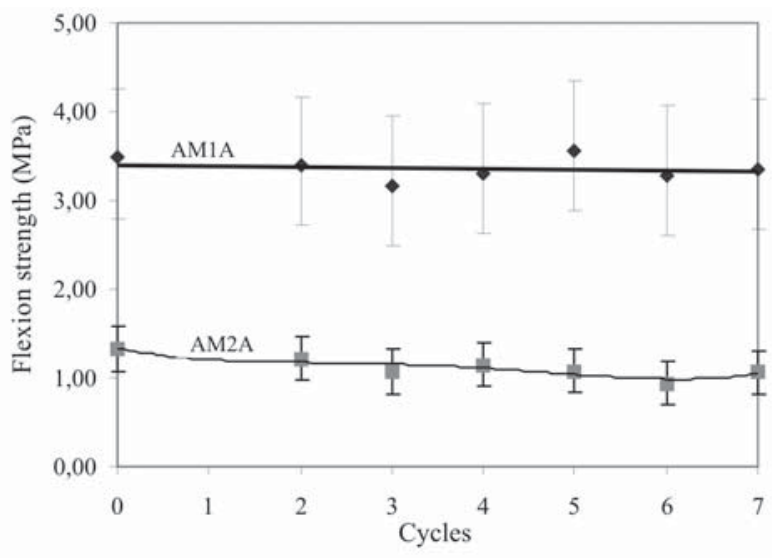

Figure 8: Average flexion strength of the AM1 and AM2 mortars subjected to wetting and drying cyclic period after 28-day aging time. [Figura 8: Resistência à flexão média das argamassas AM1 e AM2 submetidas a períodos cíclicos de molhagem e secagem após 28 dias de cura.]

formed. Most noticeably, flexion strength decreases up to 28 days on AM2A mortars probably due to the nucleation and growth of $\mathrm{CH}$ and AFm phases, which have good cleavage. Summarizing, the residue promotes the nucleation and growth of hydration products richer in calcium as well as greater amounts of calcium hydroxide. The reduction in mechanical strength of AM2A mortar is, therefore, mainly due to the interference of the residue in the hydration products as well as due to the addition of polyurethane. The polyurethane, inert but fragile, disintegrates easily under mechanical forces carrying through to the same effect observed by the polystyrene in AM1 mortar. A contribution in mechanical strength decline can be also attributed to the porosity created by the chemical reaction between the cement and the residue during the mortars manufacture (equation $\mathrm{C}$ ).

Regarding the AM1F and AM2F mortars, the initial drying in furnace provokes a delay in the hydration process due to water shortage. The necessary water to hydrate the cement is then captured from the environment, taking more time to reach the same hydration level of the AM1A and AM2A mortars. This delay in the hydration process is, therefore, reflected in the mechanical behavior of AM1F and AM2F mortars where their values are lower than those of AM1A and AM2A respectively, after 7 and 14 days of aging time.

\section{CONCLUSIONS}

The textile residue is basically composed of calcium carbonate and calcium hydroxide.

The textile residue reacts chemically with the cement when both are mixed with water promoting the nucleation and growth of cement compounds richer in calcium as well as greater amounts of calcium hydroxide.

The initial drying in furnace causes a delay in the hydration process.

The AM1A mortar, aged without initial drying in furnace, presented a normal hydration compared to the standard mortar
(SM). The hydration products more likely to be present are $\mathrm{CH}, \mathrm{C}-\mathrm{S}-\mathrm{H}, \mathrm{AFm}$ and $\mathrm{AFt}$ phases.

The mechanical strength of the polystyrene and of the polyurethane is so poor that they can be compared to cavities within the mortar, reducing the mechanical strength of the AM1 and AM2 mortars, respectively.

Apart from the polyurethane, the negative effect in mechanical strength of AM2 mortar is due to the influence of the residue in the hydration products, and also due to the porosity generated during the chemical reaction between the cement and the residue.

The residue promotes the nucleation and growth of hydration products (C-S-H, AFm and AFt phases) high in calcium as well as greater amounts of calcium hydroxide $(\mathrm{CH})$. The pastes produced with residue contain also significant amounts of $\mathrm{CaCO}_{3}$.

The AM2 mortar presents mechanical strength slightly superior to $1 \mathrm{MPa}$, as required, in the late period of hydration.

The wetting and drying cyclic test do not interfere, at least significantly, in the mechanical stability of the alternative mortars (AM1A and AM2A).

Chemical analyses of the leached materials showed that the chemical elements analyzed presented concentrations below the maximum limits established by the Brazilian NBR 10004 code.

Lastly, to reach a more conclusive result in solubilization test, further analyses are required to eventually make some arrangements in cement and/or AM2 mortar compositions.

\section{ACKNOWLEDGEMENTS}

The authors gratefully acknowledge financial support from CAPES (Federal government), and technical support from UDESC and FINEP (infrastructure).

\section{REFERENCES}

[1] E. Gemelli, N. H. Almeida Camargo, J. Brescansin, Mater. Res. 4, 4 (2001) 297.

[2] A. B. Masuero, D. C. C. Dal Molin, A. F. Vilela, Proc. of the $13^{\text {th }}$ Brazilian Congress of Materials Science and Engineering, Curitiba, PR (1998) cdrom, p. 4769-4778.

[3] A. W. Moura, D. C. C. Dal Molin, A. F. Vilela, Proc. $13^{\text {th }}$ Brazilian Congress of Material Science and Engineering, Curitiba, PR (1998) cdrom, p. 3403-3412.

[4] A. P. Watanabe, J. J. Nunes, L. Rebello, M. A. Moreno, J. M. M. Mendes, P. M. Buchler, Proc. $28^{\text {th }}$ Brazilian Congress of Ceramics, Criciuma, SC (1994) cdrom, p. 546-551.

[5] N. H. Almeida Camargo, R. L. Pereira, E. Gemelli, M. V. Folgueras, F. Karvat, Proc. $47^{\text {th }}$ Brazilian Congress of Ceramics, J. Pessoa, PB (2003) cdrom, p. 2295-2307.

[6] H. F. W. Taylor, "Cement Chemistry", Academic Press, London (1990) p. 1, 92, 123-198.

[7] P. K. Metha, "Concreto: estruturas, propriedades e materiais”, Pini Ed., S. Paulo (1994) 187-238.

[8] M. R. Silva, "Materiais de construção", Pini Ed., 2 ${ }^{\text {nd }}$ Ed., S. Paulo (1991) 150-189.

(Rec. 15 /06/04, Ac. 15/08/04) 